\title{
APOKRYF ARAMAJSKI KSIĘGI RODZAJU
}

Wiadomo, że w grocie pierwszej odkryto w dzbanach glinianych dokumenty tak biblijne (Księgę Izajasza w hebrajskim tekście pełnym i niepełnym, tekst dwu rozdziałów Księgi Habakuka, fragmenty rękopisów ksiąg Starego Testamentu) jak i pozabiblijne (Komentarz do wspomnianych dwu rozdziałów Księgi Habakuka, apokryf p.n. Wojna synów światłości z synami ciemności, zbiór psalmów, Księgę Reguły). Wszystkie powyższe dokumetny zostały opublikowane i doczekały się szczegółowych opracowań bądź w formie monografii, bądź też licznych artykułów. Jedynie zwój ostatni do niedawna okryty był nimbem tajemniczości. Niemal 10 lat współczesna archeologia i biblistyka czekały na to, by zaznajomić się z treścią ostatniego spośród odkrytych w 1947 r. manuskryptów pierwszej groty (1 Q).

Wiadomo także, że metropolita syryjski Atanazjusz J. Samuel zwój ten wraz z innymi przekazał w 1949 r. Stanom Zjednoczonym a konkretnie Amerykańskiej Szkole Badań Wschodu.

\section{ODCZYTANIE ZWOJU}

Zanim jednak zwoje te doczekały się opracowania w Amerykańskiej Szkole Badań Wschodu, jednemu z uczonych amerykańskich nazwiskiem J. C. Trever udało się dwukrotnie, raz w 1948 r., a drugi raz w 1949 r., od całego zwoju oderwać niewielki fragment, liczący zaledwie 34 wierszy o wymiarach $12,1 \times 21,7 \mathrm{~cm}$. Po zrobieniu zdjęcia kolorowego J. C. Trever zdołał odczytać znajdujące się na nim litery. Odczytany tekst przesłał on następnie znakomitemu archeologowi W. F. Albrightowi, który orzekł, że odnaleziony dokument zawiera 
tekst aramajski Ks. Henocha, aczkolwiek nie posiada on żadnej paraleli z Ks. Henocha, zachowaną w języku greckim i etiopskim.

To stwierdzenie W. F. Albrighta nie wszystkich jednak zadowoliło. W wyniku dalszych badań szczególniejszą uwage zwrócono na wyraz „bt'ns”, występujący w wierszach 2 i 8 oderwanego fragmentu. Spostrzeżono także, że znajduje się on również w apokryfie p.n. Księga Jubileuszów (4, 28), który jest określeniem żony Lamecha. Ponieważ zaś imię Lamech Księgi Jubileuszów utożsamić można z tym samym imieniem występującym w wierszach 2, 3 i 19 naszego fragmentu, oraz ponieważ w wierszach 2 i 3 Lamech przemawia w pierwszej osobie liczby pojedynczej „Potem spieszyłem sie ja, Lamech, do Bit'enos", można przypuszczać, iż mamy tu do czynienia z zaginionym apokryfem „Księgi Lamecha”, której tytuł zachował się jednak w starożytnym spisie apokryfów ${ }^{1}$ ).

Stanowisko J. C. Trevera podziela także C. Torrey, lecz dodaje szereg nowych szczegółów, zaczerpniętych $z$ analizy porównawczej naszego fragmentu z etiopską Ksiegą Jubileuszów.

Wydawało się zatem, że nierozwinięty do niedawna zwój, został już o wiele wcześniej rozpoznany, zidentyfikowany i częściowo odczytany i to przez ludzi o nazwiskach światowych. Szczególnie powaga W. F. Albrighta jest zbyt wielka, by orzeczenie jego można kwestionować ${ }^{2}$ ).

Dopiero, gdy w 1954 r. państwo Izrael zakupiło wspomniane zwoje i sprowadziło je do Jerozolimy, okazało się, że stanowisko podzielane przez w/w uczonych amerykańskich jest niesłuszne. Dowiódł tego, wbrew horoskopom G. Moliny ${ }^{3}$ ), J. Biberkraut, który rozwinął ów zwój i stwierdził, że wcale nie mamy tu do

1) E. Schürer, Geschichte des jüdischen Volkes im Zeitalter Jesu Christi, Leipzig ${ }^{4}, 1909$, t. 3, s. 358.

$\left.{ }^{2}\right)$ O. Eissfeldt, Die Bestimmung der aramäisch geschriebenen Rılle als das apokryphe Lamech-Buch, art. w: Theologische Literaturzeitung 75 (1950) 23-26.

$\left.{ }^{3}\right)$ Die Söhne des Lichtes, Wien, 1952, s. 101: Ihre Veröffentlichung ist auch in der nächsten Zeit nicht zu erwarten. 
czynienia ani z Księgą Henocha, ani też Apokalipsą Lamecha, lecz $z$ ludowym tłumaczeniem - parafrazą kanonicznego tekstu Księgi Rodzaju (5, 28-15, 4), utrzymanym w stylu pism apokryficznych takich, jak np. Księga Jubileuszów, Liber Antiquitatum Biblicarum Pseudo-Filona, lub Midraszu.

Obawy G. Moliny nie były jednak pozbawione podstaw, gdyż prace nad rozwinięciem zwoju okazały się rzeczywiście nader uciążliwe, ze względu na to, iż materiał zwoju był kruchy, łamliwy, bliski rozpadnięcia ${ }^{4}$ ).

Opublikowaniem zwoju zajęli się Nahman Avigad i Yigael Yadin ${ }^{5}$ ).

Stan zwoju, którego szerokość wynosi $34,5 \mathrm{~cm}$, a długość $2,75 \mathrm{~m}$, jak również stosunkowo krótki okres czasu, nie pozwoliły wydawcom na odczytanie i opublikowanie wszystkich 22 kolumn tekstu apokryfu aramajskiego Księgi Rodzaju, lecz jedynie najłatwiejszych do odczytania. Publikacja tekstów przed odczytaniem całości miała na celu udostępnienie przynajmniej ogólnej treści ostatniego zwoju groty pierwszej (1Q).

Na całość publikacji Nahmana Avigada i Yigael Yadina składają się trzy części. W części pierwszej, która posiada charakter wstępu, wydawcy podają w języku hebrajskim szeroki i wnikliwy opis zwoju i treść kolumn. Uwagi krytyczne, oraz stosunek treści kolumn XIX-XXII do ksiąg Starego Testamentu, apokryfów i targumów oraz neohebrajski przekład treści kolumn: II, XIX, XX, XXI i XXII obejmuje część tr z eci a. Część natomiast druga, środkowa, zawiera fascimile owych pięciu kolumn wraz z nader łatwo czytelną transkrypcją tekstów aramajskich.

Wartość owej publikacji jest tym cenniejsza, iż równocześnie

$\left.{ }^{4}\right)$ M. Burrows, The Dead Sea Scrolls, New York ${ }^{7}, 1956$, s. 26 n.

${ }^{5}$ ) A Genesis Apocryphon. A Scroll from the Wilderness of Judea. Description and Contents of the Scroll, Facsimiles, Transcription and Translation of Columns II, XIX-XXII, Jerusalem 1956; N. Avigad, Last of the Dead Sea Scrolls unrolled, art. w: Bibl. Archaeol. 19 (1956) $22-24$. 
podany jest w niej przekład angielski ,słowa wstępnego" wydawców (s. 7-9), opisu i syntezy treści tekstów zwoju (s. 1239) i wreszcie wszystkich dotychczas opublikowanych tekstów aramajskich (s. 40-48). Przeklàd ten na język angielski zawdzięczać należy mieszkance Jerozolimy Sulamith Schwartz Nardi.

\section{TREÃ Z̃ ZWOJU}

Przejdźmy teraz do treści odczytanych kolumn. K ol u m n a II zawiera opis narodzin Noego. Wykazuje ona duże podobieństwo do opisu podanego w r. $106 \mathrm{Ks}$. Henocha.

Tekst kolumn XIX do XXII w zasadzie odpowiada treści rr. 12-15, 4 Księgi Rodzaju. Jest on nadto wzbogacony licznymi opowiadaniami i legendami z życia patriarchów, dotąd całkowicie nieznanymi i nie znajdującymi się w tekstach kanonicznych.

I tak tekst kolumny XIX odpowiada treści r. 12-tego Księgi Rodzaju, a więc obejmuje opis wędrówki Abrama ku Południowi $(12,9)$. Tak omawiany apokryf jak również Ks. Jubileuszów wymieniają Hebron jako miejscowość nawiedzoną straszną klęską głodową (Rodz 12, 10), której Abram unika dzięki przeniesieniu się do Egiptu. Ww. 14-18a tejże kolumny podają opis snu, jaki nawiedził Abrama. Wspomniany opis nieznany jest jednak tekstowi kanonicznemu. Apokryf, podobnie jak i tekst kanoniczny, mówi dalej o „książętach faraonowych" i dodaje, że jeden z nich nosił imię Hrqnus.

$\mathrm{K}$ ol um a XX, w wierszach $2-8$ zawiera nieznany dotąd opis fizycznego wyglądu Sary, który podaje faraonowi ów książę Hrqnws. Oprócz piękności apokryf przypisuje Sarze niezwykłą mądrość. Ww. 16-32 tejże kolumny pod względem treściowym odpowiadają $w$ zasadzie Ks. Rodz 12, 17-20 i Ks. Jubileuszów 13, 13-15 a, a 2 ostatnie wiersze 33 i 34 treści Ks. Rodz 13, 1-2 i Ks. Jubileuszów 13, 14.

$\mathrm{K}$ ol um a XXI, której tekst jest stosunkowo dobrze zachowany, od w. 1-22 odpowiada treści Rodz. 13, 3-18, a wiersze $23-34 \mathrm{Ks}$. Rødz 13, 1-12 i Księdze Jubileuszów 13, $22 \mathrm{n}$. W apokryfie natomiast mocno jest skrócony opis sporu 
między pasterzami Abrama i Lota (Ks. Rodz 13, 5, 21). Opis ten zawierają jedynie ww. 5 i 7 tejże kolumny. Treść ww. 13-18 dostarcza szeregu nowych, dotąd nieznanych informacji topograficznych. Tekst ww. 19-22 odpowiada treści Ks. Rodz 13, 18 i Ks. Jubil 13, 21. Wiersze 23-34 podają barwny opis wojny pięciu królów (Ks. Rodz 14, 1-12; Ks. Jubil 13, $22 \mathrm{n}$.). W opisie tym napotykamy na szereg nowych nazw miejscowości i osób np. znany król Arioch jest według apokryfu (w. 23) władcą krainy Kptin (= Kapadocji? - zdaniem prof. B. Mazarsa), a nie Ellasar (Ks. Rodz. 14, 1). Gebal wymienia apokryf jako siedzibę Hurrim (w. 29).

Najlepiej przechował się tekst kolumny XXII, który w wierszach 1-12a odpowiada treściowo Ks. Rodz 14, 13-16, a $12 \mathrm{~b}-26 \mathrm{Ks}$. Rodzaju 14, 17-24; i Ks. Jubil 13, 28 nn, zaś ww. 27-34 Ks. Rodz 15, 1-4 i Ks. Jubil 14, 1-4.

$\mathrm{Na}$ szczególną uwagę zasługuje treść w. 13 tejże kolumny, gdzie Salem utożsamione jest z Jerozolimą podobnie jak w pismach Józefa Flawiusza (Bell. Jud. VI, 438; Antiq. I, 180). Identyfikacji tego rodzaju nie spotykamy w opisie Ks. Rodz 14, 18.

Identyfikacja taka posiada jednak bardzo mały stopień prawdopodobieństwa z punktu widzenia historycznego, gdyż miejscowości Salem, stanowiącej posiadłość króla Melchizedeka szukać należy raczej w pobliżu Sychem. Powtóre, w czasie, z którego pochodzi omawiany apokryf, Judejczycy i Samarytanie nienawidzili się, i dlatego właśnie należy przypuścić, że autor celowo utożsamiał tę miejscowość przewidując oburzenie jerozolimskich klas kapłańskich z tego powodu, że słuchaczom ich przypominałoby się stare legendy z życia patriarchów mówiące o tym, że Melchizedek, który był przecież kapłanem Boga Najwyższego, Bogu temu oddawał cześć w miejscowości położonej na terenie znienawidzonej Samarii ${ }^{6}$ ).

$\left.{ }^{6}\right)$ P .Winter, Der gegenwärtige Stand der Erforschung der in Palästinà neu gefundenen hebräischen Handschriften. 38. Das aramäische Gene'sis - Apokryphon, art. w: Theol. Literaturzeitung 82 (1957) 257-262; E. Vogt, Volumen Midrasz Geneseos ex Qumran art w: Biblica 37 (1956) 263. 


\section{CZAS POCHODZENIA APOKRYFU}

Wydawcy apokryfu aramajskiego Ks. Rodzaju, w oparciu o dotychczas opublikowane kolumny, są zdania, że pochodzi on bądź z końca I w. przed Chr. bądź też z pierwszej połowy I w. po Chr. Nadto spośród odnalezionych zwojów apokryf ten wykazuje największe podobieństwo do poematu p.n. Walka synów światłości z synami ciemności.

Nahman Avigad i Yigael Yadin twierdzą dalej, że sam apokryf jako taki jest o wiele starszy, aniżeli omawiany przez nas manuskrypt, starszy także od Ks. Henocha i Ks. Jubileuszów. Mianowicie pochodzi on najprawdopodobniej z III w. przed Chr., a jeg językiem pierwotnym był język hebrajski. Znajdujący się obecnie w naszym posiadaniu apokryf jest zatem przekładem z tekstu hebrajskiego.

\section{ZNACZENIE APOKRYFU}

$\mathrm{Na}$ podstawie dotychczas opublikowanego i mniej niż w 1/4 odczytanego tekstu apokryfu trudno wysnuwać wnioski ostateczne o znaczeniu i wartości tekstu. Rozwinięte dotąd teksty upoważniają nas jednak do stwierdzenia faktu, że apokryf ten wnosi wiele cennych szczegółów topograficznych, dając w ten sposób możność dokładniejszego poznania geografii starej $\mathrm{Pa}-$ lestyny.

Także dla historii religii jest on dokumentem nie bez znaczenia, gdyż pozwala na ustalenie tak miejsca jak i sposobu kształtowania się tekstu kanonicznego Ks. Rodzaju.

Swoistą wymowę posiada apokryf ten dla starożytnej historii literatury, szczególnie gdy zestawi się go z Księgą Jubileuszów, Liber Antiquitatum Biblicarum tzw. Pseudo-Filona, z pismami Józefa Flawiusza, Targumami i Midraszem.

Najdonioślejsze znaczenie ma już dzisiaj ów apokryf dla językoznawstwa. Poraz pierwszy bowiem jesteśmy w posiadaniu oryginalnego dokumentu palestyńskiego, pokrytego pismem aramajskim, używanym na terenie Palestyny na przełomie I w. przed i I w. po Chr. Wspomniany język aramajski 
nie jest jednak wcale językiem ,urzędowym”, z jakim spotykamy się np. w Księdze Ezdrasza czy Daniela, lecz językiem ludowym, zbliżonym do języka hebrajskiego Ksiąg Starego Testamentu. Jest to język aramajski silnie shebraizowany.

Należy się spodziewać, że pełna publikacja tekstów apokryfu aramajskiego Księgi Rodzaju wniesie jeszcze niejeden nowy szczegół dotyczący problematyki qumrańskiej.

Kraków, Ks. LUDWIK STEFANIAK, C. M. 